\title{
Is the infertility in hypothyroidism mainly due to ovarian or pituitary functional changes?
}

\section{Armada-Dias ${ }^{1}$, J.J. Carvalho², M.M.D. Breitenbach ${ }^{1}$, C.R. Franci ${ }^{3}$ and E.G. Moura ${ }^{1}$}

\author{
Departamentos de ${ }^{1}$ Fisiologia and ${ }^{2} \mathrm{H}$ istologia e Embriologia, \\ Instituto de Biologia Roberto Alcântara Gomes, \\ Universidade do Estado do Rio de Janeiro, Rio de Janeiro, RJ, Brasil \\ ${ }^{3}$ Departamento de Fisiologia, Faculdade de Medicina de Ribeirão Preto, \\ Universidade de São Paulo, Ribeirão Preto, SP, Brasil
}

\section{Correspondence \\ E.G. Moura \\ Departamento de Fisiologia \\ Instituto de Biologia \\ IB, UERJ \\ Boulevar 28 de Setembro, 87 \\ Fundos, 50 andar \\ 20551-030 Rio de Janeiro, RJ \\ Brasil \\ Fax: + 55-21-587-6129 or 587-6134 \\ E-mail: egmoura@uerj.br \\ Research supported by $\mathrm{CNPq}$ and SR-2 UERJ. Publication supported by FAPESP.}

Received April 17, 2001 Accepted June 5, 2001

\section{Abstract}

The objective of the present study was to examine whether hypothyroidism affects the reproductive system of adult female rats by evaluating ovarian morphology, uterus weight and the changes in serum and pituitary concentrations of prolactin and gonadotropins. Three-monthold female rats were divided into three groups: control $(\mathrm{N}=10)$, hypothyroid $(\mathrm{N}=10)$, treated with $0.05 \%$ 6-propyl-2-thiouracil (PTU) in drinking water for 60 days, and $\mathrm{T}_{4}$-treated group $(\mathrm{N}=10)$, receiving daily $s c$ injections of L-thyroxine $(0.8 \mu \mathrm{g} / 100 \mathrm{~g}$ body weight) during the last 10 days of the experiment. At the end of 50 days of hypothyroidism no hypothyroid animal showed a regular cycle, while $71 \%$ of controls as well as the $\mathrm{T}_{4}$-treated rats showed regular cycles. Corpora lutea, growing follicles and mature Graafian follicles were found in all ovaries studied. The corpora lutea were smaller in both the hypothyroid and $\mathrm{T}_{4}$-replaced rats. Graafian follicles were found in $72 \%$ of controls and only in $34 \%$ of hypothyroid and $43 \%$ of $\mathrm{T}_{4}$-treated animals. Serum LH, FSH, progesterone and estradiol concentrations did not differ among the three groups. Serum prolactin concentration and the pituitary content of the three hormones studied were higher in the hypothyroid animals compared to control. $\mathrm{T}_{4}$ treatment restored serum prolactin concentration to the level found in controls, but only partially normalized the pituitary content of gonadotropins and prolactin. In conclusion, the morphological changes caused by hypothyroidism can be a consequence of higher prolactin production that can block the secretion and action of gonadotropins, being the main cause of the changes observed.

\section{Introduction}

It is well known that hypothyroidism impairs reproductive function both in humans and experimental animals. However, the mechanism of this dysfunction has not been
Key words - Hypothyroidism

- Prolactin

- Gonadotropins

- Folliculogenesis

- Estrous cycle completely established. In several species irregular estrous cycles were also detected $(1,2)$. Ovary atrophy was reported when hypothyroidism was induced in adult female rats (3). Chan and $\mathrm{Ng}$ (4) failed to observe morphological changes in the uterus and fal- 
lopian tubes when hypothyroidism was induced in rats on postnatal day one; however, they showed a decrease in the number of primordial, antral and Graafian follicles, with no considerable consequences for reproduction in these animals. Dijstra et al. (5) reported disturbed folliculogenesis and absence of corpora lutea when hypothyroidism was induced since birth. In women, hypothyroidism is associated with delay in the onset of puberty (6), anovulation (7), amenorrhea or hypermenorrhea, menstrual irregularity, infertility and increased frequency of spontaneous abortions (8-10). It was suggested that these alterations may be caused by a decrease in LH secretion. An increase in the incidence of galactorrhea caused by hyperprolactinemia has been observed in hypothyroid women. Prolactin decreases GnRH secretion (11), LH frequency and pulsatility (12), counteracts the morphological effects of LH in culture of granulosa cells (13), having a luteolytic effect (14) and causing inhibition of folliculogenesis (15), estrogen synthesis (16), and ovulation (17). This could explain the decrease in gonadotropin stimulation in the ovaries of hypothyroid women. However, there is a scarcity of data associating the increase in prolactin production in hypothyroidism under experimental conditions and the changes in ovary cycle, morphology and gonadotropin production.

In the present study our aim was to examine whether hypothyroidism affects the reproductive system of adult female rats by evaluating several aspects of the hormonal regulation and morphological analysis of the ovary, particularly the changes in serum and pituitary concentrations of prolactin and gonadotropins.

The objective of the present investigation was to study simultaneously several parameters for the evaluation of reproductive function in hypothyroid states that are usually not present together in other reports.

\section{Material and Methods}

\section{Animals}

Thirty 3-month-old female Wistar rats presenting regular estrous cycles were selected and divided into three experimental groups: control $(\mathrm{N}=10)$, hypothyroid $(\mathrm{N}=$ 10), treated with $0.05 \%$ 6-propyl-2-thiouracil (PTU, Sigma, St. Louis, MO, USA) in drinking water for 60 days (18), and $\mathrm{T}_{4^{-}}$ treated group $(\mathrm{N}=10)$, receiving daily $s c$ injections of L-thyroxine $(0.8 \mu \mathrm{g} / 100 \mathrm{~g}$ body weight) during the last 10 days of the experiment. The other two groups received $s c$ injections of saline for the same period of time as $\mathrm{T}_{4}$ treatment. Vaginal smears were evaluated during the last 20 days of the experiment. The rats were killed by decapitation and pituitary, uterus and ovaries were dissected and weighed. Trunk blood was collected for the determination of serum concentrations of progesterone, estradiol, TSH, FSH, LH and prolactin.

\section{Histological analysis}

The ovaries were dissected out and fixed directly in Bouin's fixative overnight for histological examination. The ovaries were cut into 5-7- $\mu \mathrm{m}$ thick sections and stained with hematoxylin and eosin. For each ovary, at least five sections were selected, and the total number of corpora lutea and Graafian follicles was counted under the light microscope $(19,20)$. The follicles were classified as secondary when they presented two or more layers of granulosa cells and as antral when they contained fluid. For an antral follicle to be considered mature or Graafian, the oocyte has to occupy an excentric position and the antral cavity must be completely filled with fluid, with the presence of cumulus oophorus, corona radiata and cellular peduncle $(21,22)$. The corpora lutea were measured using a computer-assisted morphometric program 
(KS400/Zeiss Vision).

\section{Radioimmunoassays}

Pituitaries were homogenized in $500 \mu \mathrm{l}$ of $1 \% \mathrm{PBS} / \mathrm{BSA}$ buffer and centrifuged at $3,000 \mathrm{rpm}$ at $4^{\circ} \mathrm{C}$ for $15 \mathrm{~min}$, and $\mathrm{LH}, \mathrm{FSH}$ and prolactin were measured in the supernatant. TSH, LH, FSH and prolactin were measured with kits supplied by the National Institute of Diabetes and Digestive and Kidney Diseases (Bethesda, MD, USA) and are reported in terms of the reference preparation (RP3). Within-assay variation and the coefficient of variation between assays and minimum assay detection were $7.9 \%, 6.7 \%$ and $0.52 \mathrm{ng} / \mathrm{ml}$ for TSH, $3.5 \%, 16.8 \%$ and 0.04 $\mathrm{ng} / \mathrm{ml}$ for $\mathrm{LH}, 2.5 \%, 10.2 \%$ and $0.19 \mathrm{ng} / \mathrm{ml}$ for $\mathrm{FSH}$, and $2.3 \%, 12.2 \%$ and $0.19 \mathrm{ng} / \mathrm{ml}$ for prolactin, respectively.

Progesterone and estradiol concentrations in serum were determined using kits from DPC (Diagnostic Products Co., Los Angeles, CA, USA) corrected for rat serum.

\section{Statistical analysis}

Data are reported as means \pm SEM, with the level of significance set at $\mathrm{P}<0.05$. Oneway ANOVA followed by the Student-Newman-Keuls multiple comparison test was used to assess significance for all data, except morphological analysis.

\section{Results}

Hypothyroid animals showed lower body weight than controls, and $\mathrm{T}_{4}$ treatment was insufficient to normalize body weight. Ovarian weight was slightly lower in the hypothyroid group and treatment did not reverse these values. Uterine weight was significantly lower in the hypothyroid rats, and the $\mathrm{T}_{4}{ }^{-}$ treated animals showed intermediate values between controls and hypothyroid animals. Pituitary weight did not change with hypothyroidism or treatment (Table 1).

\section{Estrous cycle}

At the end of 50 days of hypothyroidism no animal showed a regular cycle in the PTU-treated group, while 5 out of 7 animals showed regular cycles in the control group. After $\mathrm{T}_{4}$ treatment the cycle showed no difference between control and PTU $+\mathrm{T}_{4}$ group (Table 2).

\section{Morphology}

Corpora lutea, growing follicles and mature Graafian follicles were found in all ovaries studied. However, the corpora lutea were smaller in number and diameter in hypothyroid rats. $\mathrm{T}_{4}$ treatment did not reverse this alteration (diameter: control, $0.42 \pm 0.06$; hypothyroid animals, $0.33 \pm 0.02 ; \mathrm{T}_{4}$-treated group, $0.36 \pm 0.03 \mu \mathrm{m}^{2}$, and number: con-

Table 1. Body, pituitary, uterus and ovarian weights of control, PTU-treated and $\mathrm{T}_{4}$-treated hypothyroid rats.

\begin{tabular}{|c|c|c|c|c|c|c|c|}
\hline \multirow[t]{2}{*}{ Groups } & \multirow{2}{*}{$\begin{array}{c}\text { Body weight } \\
\text { (g) }\end{array}$} & \multicolumn{2}{|c|}{ Uterus } & \multicolumn{2}{|c|}{ Ovary } & \multicolumn{2}{|c|}{ Pituitary } \\
\hline & & $\mathrm{mg}$ & $\mathrm{mg} / \mathrm{mg} \times 10^{-2} \mathrm{bw}$ & $\mathrm{mg}$ & $\mathrm{mg} / \mathrm{mg} \times 10^{-2} \mathrm{bw}$ & $\mathrm{mg}$ & $\mathrm{mg} / \mathrm{mg} \times 10^{-2} \mathrm{bw}$ \\
\hline Control & $184 \pm 6.6$ & $585 \pm 0.03$ & $320 \pm 0.4$ & $74 \pm 8.4$ & $40.2 \pm 0.12$ & $10.4 \pm 0.6$ & $5.6 \pm 0.3$ \\
\hline PTU & $142 \pm 1.5^{+}$ & $367 \pm 0.02^{+}$ & $260 \pm 1.3^{+}$ & $53 \pm 9.2$ & $37.3 \pm 0.61^{+}$ & $8.8 \pm 0.5$ & $6.1 \pm 0.3$ \\
\hline $\mathrm{PTU}+\mathrm{T}_{4}$ & $153 \pm 5.8^{*}$ & $410 \pm 0.03$ & $270 \pm 0.5^{+}$ & $50 \pm 1.7$ & $32.6 \pm 1.7^{+}$ & $8.5 \pm 0.7$ & $5.4 \pm 0.3$ \\
\hline
\end{tabular}

Data are reported as means \pm SEM. bw = body weight. PTU = 6-propyl-2-thiouracil-induced hypothyroid rats; PTU $+\mathrm{T}_{4}=$ PTU-induced hypothyroid rats treated with thyroxine.

$+\mathrm{P}<0.001$ vs control; $* \mathrm{P}<0.005$ vs control (Student-Newman-Keuls multiple comparison test). 
Table 2. Percentage of estrous cycle irregularities in control rats, hypothyroid rats and rats submitted to $\mathrm{T}_{4}$ replacement.

\begin{tabular}{|c|c|c|c|c|c|c|}
\hline \multirow[t]{2}{*}{ Groups } & \multicolumn{3}{|c|}{50 days of PTU (\%) } & \multicolumn{3}{|c|}{$\begin{array}{l}60 \text { days of PTU and } \\
10 \text { days of } T_{4}(\%)\end{array}$} \\
\hline & NC & IC & DIla & NC & IC & DIla \\
\hline Control & $71(5 / 7)$ & $29(2 / 7)$ & $0(0 / 7)$ & $86(6 / 7)$ & $14(1 / 7)$ & $0(0 / 7)$ \\
\hline PTU & 0 (0/13) & $38(5 / 13)$ & $62(8 / 13)$ & $0(0 / 6)$ & $67(4 / 6)$ & $33(2 / 6)$ \\
\hline $\mathrm{PTU}+\mathrm{T}_{4}$ & - & - & - & $71(5 / 7)$ & $29(2 / 7)$ & $0(0 / 7)$ \\
\hline
\end{tabular}

The number of animals affected/total animals in the group is shown in parentheses. PTU = 6-propyl-2-thiouracil-treated hypothyroid rats; PTU $+\mathrm{T}_{4}=$ PTU-induced hypothyroid rats treated with thyroxine; $\mathrm{NC}=$ normal cycle; IC = irregular cycle; $\mathrm{DIla}=$ diestrus II arrest.

Figure 1. Serum TSH concentration in controls, 6-propyl-2-thiouracil-induced hypothyroid rats (PTU) and thyroxine-replaced hypothyroid rats $\left(\mathrm{PTU}+\mathrm{T}_{4}\right)$. Data are reported as means $\pm \mathrm{SEM}$. $* \mathrm{P}<0.05$ compared with control animals and $+P<0.05$ compared with hypothyroid animals (univariate ANOVA and NewmanKeuls multiple comparison test).

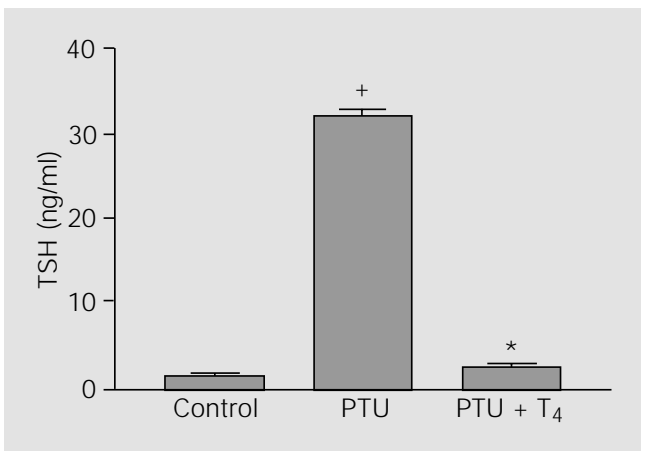

Figure 2. Serum progesterone (A) and estradiol (B) concentrations in controls ( $\mathrm{N}=9$ ), 6-propyl-2-thiouracil-induced hypothyroid rats (PTU, $\mathrm{N}=8$ ), and thyroxine-replaced hypothyroid rats (PTU $\left.+T_{4}, N=9\right)$. Data are reported as means \pm SEM (univariate ANOVA and NewmanKeuls multiple comparison test). trol, $\mathrm{N}=4$; hypothyroid animals, $\mathrm{N}=2 ; \mathrm{T}_{4-}$ treated group, $\mathrm{N}=3$ ). The presence of Graafian follicles was found in 5 of $7(72 \%)$ control animals, but only in 2 of 6 (34\%) hypothyroid animals and a discrete recovery was observed in the $\mathrm{T}_{4}$-treated group ( 3 of 7 , $43 \%)$.

\section{Hormone levels}

Serum TSH was 10 times higher in hypothyroid animals than in controls. $\mathrm{T}_{4}$ treatment restored these values close to control (Figure 1).

Serum progesterone and estradiol concentrations did not differ among the three groups (Figure 2).

Serum LH and FSH concentrations did not differ among the three groups. However, serum prolactin concentration and the pituitary content of the three hormones studied were higher than control in the hypothyroid animals. $\mathrm{T}_{4}$ treatment restored serum prolactin concentration to the level found in the control, but failed to normalize the pituitary content of LH, FSH and prolactin (Figure 3).

\section{Discussion}
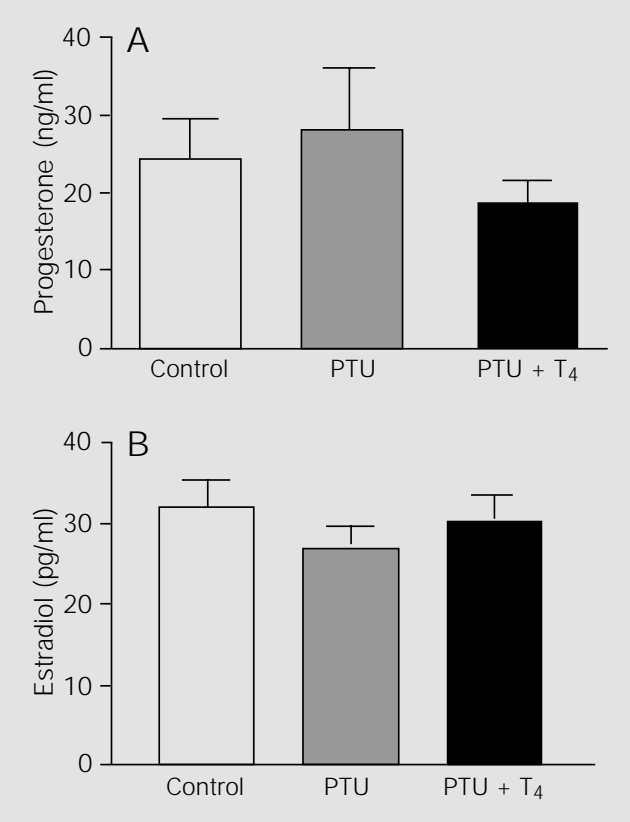

Increased serum TSH levels in PTUtreated rats and the almost normal TSH serum levels in $\mathrm{T}_{4}$-treated hypothyroid rats confirmed the effectiveness of the treatment.

Hypothyroidism caused a significant impairment in the weight of uterus and ovary, but only a slight decrease in pituitary weight. $\mathrm{T}_{4}$-replaced hypothyroid rats showed a heavier uterus than hypothyroid ones, but the relative weight was still lower than in the controls. $\mathrm{T}_{4}$ treatment was not sufficient to normalize ovarian weight, a fact probably explained by the short time of $\mathrm{T}_{4}$ replacement or a more permanent effect of severe hypothyroidism on uterine weight and ovarian morphology. These data are in agreement with a previous report by Leathern (23) studying a model of congenital hypothyroid- 
ism and by Dijstra et al. (5) who treated prepubertal rats with PTU. Our data show that, even after puberty, hypothyroidism may produce an involution of uterus and ovary.

The small changes verified in pituitary weight may reflect some maintenance of pituitary function in hypothyroidism. The data about gonadotropin secretion in hypothyroidism are still controversial (24-28), with reports of increased, decreased and normal serum levels. Ortega et al. (3) suggested a reversal to prepubertal reproductive function in adult rats turned hypothyroid based on the secretion of FSH, LH and estradiol under basal and GnRH-stimulated conditions. In our study, despite the small changes in serum LH and FSH, we found an impor- tant change in prolactin secretion. Since we found higher pituitary LH, FSH and prolactin content in hypothyroid rats in absolute terms or relative to the pituitary weight, we suggest that the synthesis of these hormones in hypothyroidism is relatively preserved and the defect is in the mechanism of secretion.

The fact that the ovarian follicles were not well developed in the hypothyroid animals despite normal serum LH, FSH, estradiol and progesterone suggests that thyroid hormones could have a direct effect on the growth of ovarian follicles, without a significant effect on sex steroid production by the ovary. In fact, $\mathrm{T}_{3}$ receptors were found in the granulosa cells of porcine (29) and human (30) ovaries. Thyroid hormones increase the

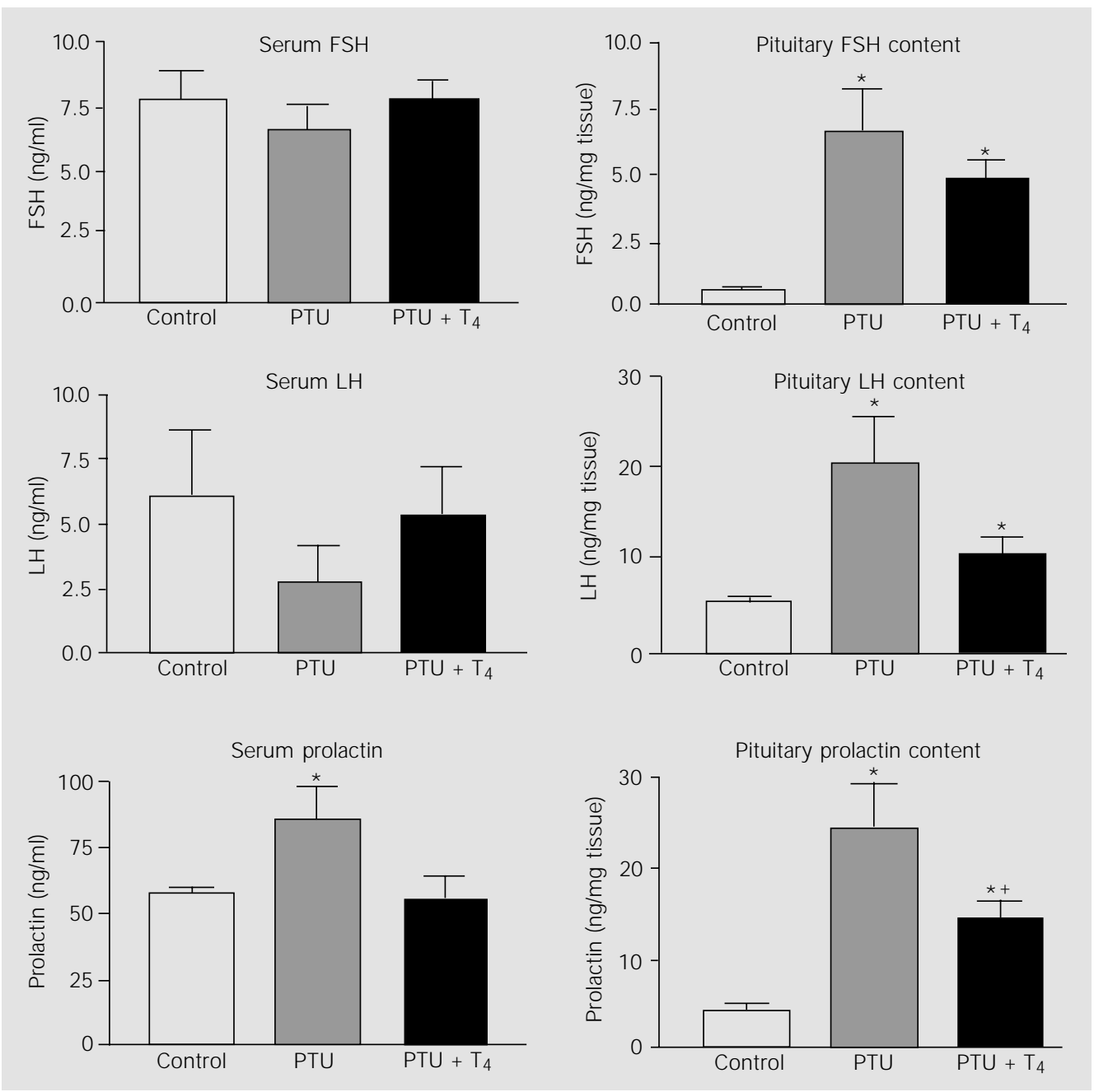

Figure 3. Serum LH, FSH and prolactin concentrations (on the left), and pituitary content (on the right) of controls, 6-propyl-2thiouracil-induced hypothyroid rats (PTU) and thyroxine-replaced hypothyroid rats (PTU + $\mathrm{T}_{4}$ ). Data are reported as means \pm SEM. $* \mathrm{P}<0.05$ compared with control animals and $+\mathrm{P}<0.05$ compared with hypothyroid animals (univariate ANOVA and Newman-Keuls multiple comparison test). 
action of FSH in cultures of porcine granulosa cells (31), suggesting a direct effect of $\mathrm{T}_{3}$ on the ovaries. Other investigators (3234) have suggested an indirect effect caused by low gonadotropic stimuli of the ovaries. We did not find any significant difference in serum gonadotropin concentrations. However, LH and FSH, despite being immunologically normal, can be biologically inactive (27). This was observed in the case of central hypothyroidism in which biological TSH abnormality was detected but with preservation of its immunoactivity (35). The same could happen as a result of lower GnRH stimuli in hypothyroid rats.

The cycle arrest in diestrus II is considered by several authors (1-3) as a signal of anovulatory cycle and usually is preceded by irregular cycles. Hypothyroid $\mathrm{T}_{4}$-replaced rats presented a partial recovery of the cycle pattern as well as follicular growth, showing that the changes observed in hypothyroid animals were not due to a toxic effect of PTU, but rather to the lack of thyroid hormones, and possibly to prolactin normalization. It is well known that $\mathrm{T}_{4}$ decreases both TRH synthesis and secretion. Thus, the decrease in prolactin observed in the $\mathrm{T}_{4}$-treated hypothyroid rats could be due to lower serum TRH concentration in this group since TRH stimulates prolactin.

The presence of corpora lutea and mature follicles, even though in smaller numbers, in hypothyroid rats could be explained by the presence of these structures before PTU treatment, since the animals were postpubertal. When the animals were treated before puberty (5), the absence of corpora lutea and a decrease of antral follicles were found. The smaller corpora lutea could explain a lower estrogen and progesterone production in the secretory phase of the estrous cycle. Since both sex steroids inhibit the synthesis of gonadotropins, the lower inhibitory action of these hormones despite normal serum concentration could explain the higher pituitary FSH and LH content in hypothyroid animals. On the other hand, higher serum prolactin concentration could be the cause of both inhibition of gonadotropin secretion (12), delay in folliculogenesis (15) and poor corpus luteum development (5).

In conclusion, hypothyroid rats had a dysfunction in the pituitary-ovarian axis that impaired follicular maturation and development of corpora lutea. The higher prolactin production could block gonadotropin secretion and action, although maintaining sex steroid production by the corpora lutea. Other studies blocking prolactin secretion in this situation are necessary to test this hypothesis.

\section{Acknowledgments}

We would like to thank Nelcir Rodrigues de Morais, Andrea Figueiredo Bertoldo and Sonia A.Z. Baptista for technical assistance.

\section{References}

1. Nesbitt J r REL, Abdul-Karim RW, Prior J T, Shelley TF \& Rourke JE (1967). Study of the effect of experimentally induced endocrine insults upon pregnant and nonpregnant ewes. III. ACTH and propylthiouracil administration and the production of polycystic ovaries. Fertility and Sterility, 18: 739-758.

2. Vriend J, Bertalanffy FD \& Ralcewicz TA (1987). The effects of melatonin and hypothyroidism on estradiol and gonadotropin levels in female Syrian hamsters. Biology of Reproduction, 36: 719-728.
3. Ortega E, Rodrigues E \& Ruiz E (1990). Activity of the hypothalamo-pituitary ovarian axis in hypothyroid rats with or without triiodothyronine replacement. Life Sciences, 46: 391-395.

4. Chan WY \& Ng TB (1995). Effect of hypothyroidism induced by propylthiouracil and thiourea on male and female reproductive systems of neonatal mice. J oumal of Experimental Zoology, 273: 160-169.

5. Dijstra G, De Rooij DG, De J ong FH \& Van Den Hurk R (1996). Effect of hypothyroidism on ovarian follicular development, granulosa cell proliferation and periphera hormone levels in the prepubertal rat. European J ournal of Endocrinology, 134: 649-654.

6. Styne DM (1991). Puberty. In: Greenspan FS (Editor), Basic and Clinical Endocrinology. Appleton, Lange \& Norwalk, London, 519-542.

7. Yen SSC (1986). Chronic anovulation caused by peripheral endocrine disorders. In: Yen SSC \& J affe RB (Editors), Reproductive Endocrinology, Physiology, Pathophysiology and Clinical Management. 
W.B. Saunders Co., Philadelphia, 441-499.

8. Montoro M, Collea J V \& Frasier SD (1981). Successful outcome of pregnancy in women with hypothyroidism. Annals of Internal Medicine, 94: 31-34.

9. Davis LE, Leveno KJ \& Cunningham FG (1988). Hypothyroidism complicating pregnancy. Obstetrics and Gynecology, 72: 108-113.

10. Longcope C (1991). The male and female reproductive systems. In: Braverman LE \& Utiger RD (Editors), The Thyroid. J.B. Lippincott Company, Philadelphia, 10521055.

11. Sarkar DK \& Yen SS (1985). Hyperprolactinemia decreases the luteinizing hormone-releasing hormone concentration in pituitary portal plasma: a possible role for ß-endorphin as a mediator. Endocrinology, 116: 2080-2084.

12. Cohen-Becker IR, Selmanoff $M \&$ Wise PM (1986). Hyperprolactinemia alters the frequency and amplitude of pulsatile luteinizing hormone secretion in the ovariectomized rat. Neuroendocrinology, 42: 328333.

13. Gitay-Goren $\mathrm{H}$, Kraiem $\mathrm{Z} \&$ Lindenbaum ES (1988). Effect of prolactin on the morphology of cultured rat granulosa cells. Cytobios, 56: 89-99.

14. Wüttke W \& Meites J (1971). Luteolytic role of prolactin during the estrous cycle of the rat. Proceedings of the Society for Experimental Biology and Medicine, 137: 988-991.

15. Larsen J L, Bhanu A \& Odell WD (1990). Prolactin inhibition of pregnant mare's serum stimulated follicle development in the rat ovary. Endocrine Research, 16: 449459.

16. Wang C, Hsueh AJ \& Erickson GF (1980). Prolactin inhibition of estrogen production by cultured rat granulosa cells. Molecular and Cellular Endocrinology, 20: 135-144.

17. Yoshimura $\mathrm{Y}$, Nakamura $\mathrm{Y}$, Yamada $\mathrm{H}$, Ando $M$, Ubukata $Y$, Oda T \& Suzuki M (1991). Possible contribution of prolactin in the process of ovulation and oocyte maturation. Hormone Research, 35: 22-
32.

18. Moura EG, Pazos-Moura CC, Dorris ML \& Taurog A (1990). Lack of effect of propylthiouracil and methylmercaptoimidazole on thyroglobulin biosynthesis. Proceedings of the Society for Experimental Biology and Medicine, 194: 48-53.

19. Meijs-Roelofs HMA, Osman $P \&$ Kramer P (1982). Ovarian follicular development leading to first ovulation and accompanying gonadotropin levels as studied in the unilaterally ovariectomized rat. J oumal of Endocrinology, 92: 341-349.

20. Teerds KJ \& Dorrington J H (1993). Immunohistochemical localization of 3ß-hydroxysteroid dehydrogenase in the rat ovary during follicular development and atresia. Biology of Reproduction, 49: 989996.

21. Fawcett DW \& Raviola E (1994). Female reproductive system. In: Bloom JR \& Fawcett DW (Editors), A Textbook of Histology. Chapman \& Hall, New York, 816831.

22. Adashi EY (1994). The ovary. In: Besser GM \& Thorner MO (Editors), Clinical Endocrinology. Wolfe, London, 12.2-12.18.

23. Leathern J H (1959). Extragonadal factors in reproduction. In: Lloyd CW (Editor), Recent Progress in the Endocrinology of Reproduction. Academic Press, New York, 170-221.

24. Baski SN (1973). Effect of propylthiouracil-induced hypothyroidism on serum levels of luteinizing hormone and folliclestimulating hormone in the rat. J oumal of Endocrinology, 59: 655-656.

25. Bruni J F, Marshall S, Dibbet J A \& Meites J (1986). Effects of hyper- and hypothyroidism on serum LH and FSH levels in intact and gonadectomized male and female rats. Endocrinology, 97: 558-563.

26. Drake TS, O'Brien WF \& Tredway DR (1980). Pituitary response to LHRH in hypothyroid women. American J ournal of Obstetrics and Gynecology, 56: 486-491.

27. Tomasi PA, Fanciulli G, Zni M, Demontis MA, Dettori A \& Delitala G (1997). Pulsatile gonadotrophin secretion in hypothy- roid women of reproductive age. European J ournal of Endocrinology, 136: 406409.

28. J iang J Y, Umezu M \& Sato E (2000). Improvement of follicular development rather than gonadotrophin secretion by thyroxine treatment in infertile immature hypothyroid RDW rats. J ournal of Reproduction and Fertility, 119: 193-199.

29. Wakim NG, Ramani N \& Rao CV (1987). Triiodothyronine receptors in porcine granulosa cells. American J ournal of Obstetrics and Gynecology, 156: 237-240.

30. Wakim AN, Polizotto SL, Buffo MJ, Marrero MA \& Burhold DR (1993). Thyroid hormones in human follicular fluid and thyroid hormone receptors in human granulosa cells. Fertility and Sterility, 59 : 1187-1190.

31. Maruo T, Hayashi $M$, Matsuo $H$, Yamamoto T, Okada H \& Mochizuki M (1987). The role of thyroid hormone as a biological amplifier of the actions of folliclestimulating hormone in the functional differentiation of cultured porcine granulosa cells. Endocrinology, 121: 1233-1241.

32. Kosco MS, Bolt DJ, Wheaton JE, Loseth KJ \& Crabo BG (1987). Endocrine response in relation to compensatory testicular growth after neonatal hemicastration in boars. Biology of Reproduction, 36: 1177-1185.

33. Van Capellen WA, Meijs-Roelofs HMA Kramer P \& Van Den Dungen HM (1989). Ovarian follicle dynamics in immature rats treated with a luteinizing hormone-releasing hormone antagonist (Org. 30276). Biology of Reproduction, 40: 1247-1256.

34. Heidel J J \& Treinen KA (1989). Physiology of the male reproductive system: endocrine, paracrine and autocrine regulation. Toxicologic Pathology, 17: 411-445.

35. Beck-Peccoz P, Amr S, Menezes-Ferreira MM, Faglia G \& Weintraub BD (1985). Decreased receptor binding of biologically inactive thyrotropin in central hypothyroidism: effect of treatment with thyrotropinreleasing hormone. New England J oumal of Medicine, 312: 1085-1090. 